\title{
How Sustainable is a Conventional Building?
}

\author{
Yashwanth Pamu \\ Assoc. Professor, CVR College of Engineering/Civil Engg. Department, Hyderabad, India \\ Email: yashwanthpamu@gmail.com
}

\begin{abstract}
India is one of the largest energy utilizing countries, China and United States of America being the first and the second respectively. Developed countries have already adopted mandatory reduction in energy utilization per GDP. But India has not fixed any such targets though the target of achieving $175 \mathrm{GW}$ of clean energy is in the process. Building or construction industry is a major consumer of energy and therefore there is a scope for reduction in energy consumption by adopting green building policies by new and existing buildings. In India, IGBC and GRIHA are the organizations which certify buildings whether green or not, based on many parameters. These parameters aim at reducing the load on the environment. One such important parameter is energy, including energy consumption, alternate ways of producing energy. Every building can be close to a green building to a little extent. This paper attempts to assess how close a conventional building is to a green building based on IGBC standards.
\end{abstract}

Index Terms: Alternative materials, Environmental load, Rating systems, Energy, IGBC, GRIHA

\section{INTRODUCTION}

The building foot print in our country is increasing at a faster rate than expected. This is a positive sign for the country in terms of economic growth. But at the same time, the $\mathrm{CO}_{2}$ emissions are also increasing at the same rate. Abanda and Byers have investigated that the buildings utilized $32 \%$ of global energy and responsible for $19 \%$ energy related greenhouse gases [1]. There is an immediate need to introduce the concepts of green buildings which can help in the growth of the country in a sustainable way.

Green measures in existing buildings can help to address international issues like reduction in $\mathrm{CO}_{2}$ emissions, reduction in usage of natural resources, usage of renewable energy, recycling of waste, recycling and reuse of water and water efficiency. Waidyasekara et al., highlighted the significance of addressing the environmental pollution caused by waste water because of construction activities [12]. Gupta and Kumar have mentioned that the building construction industry utilizes $40 \%$ of stone, sand and gravel internationally [5]. Implementation of green measures can enhance a person's health and reduce the stress. Attom, Abed, Elemam, Nazal and ElMessalami have stressed that buildings consume $16 \%$ of water worldwide [2]. Guggemos and Horvath have specified that the construction sector is one of the largest users of water and energy [4].

Green measures can be systematically implemented in existing buildings with the help of green building rating systems. Vierra cited that there are about 600 rating systems globally [11]. The two rating systems widely used in India are GRIHA and IGBC. Pamu et al., summarized that IGBC rating system has many advantages over GRIHA rating system as IGBC is easy to understand and analyze. GRIHA rating system is complicated and difficult to understand for a common man [9]. With the increase in awareness among the people, it is easy to motivate them to practice sustainable measures in our everyday life. Sev documented that the building environmental assessment tools have become popular in recent times and fascinated the construction industry [10]. Pamu and Kona stated that a green building is the one, which minimizes the negative impacts of construction right from its stages of design to its operation and maintenance stage [8]. Hikmat et al., stated that green building assessment tools offer a means to demonstrate that the building is successful in meeting $\mathrm{n}$ expected level of performance [6]. This paper gives a basic idea on how easy it is to transform an existing traditional building into a green building.

\section{Green Building Certification}

Boonstra and Petterson highlighted the necessity of environmental assessment methods which respond to environmental issues and define sustainable levels [3]. IGBC green existing buildings O\&M certification system is the first program developed in India for existing buildings. The rating system will be reviewed periodically and updated based on the innovations and market requirements. The stakeholders will play an important role in updating the rating systems. The certification system encourages the use of Indian building standards and codes in order to avoid deviation from Indian standards.

The IGBC flow chart for green building certification is shown in figure 1[7]. The figure shows the process of certification right from registration to award of rating.

\section{Registration}

Implementation of Green measures by the School
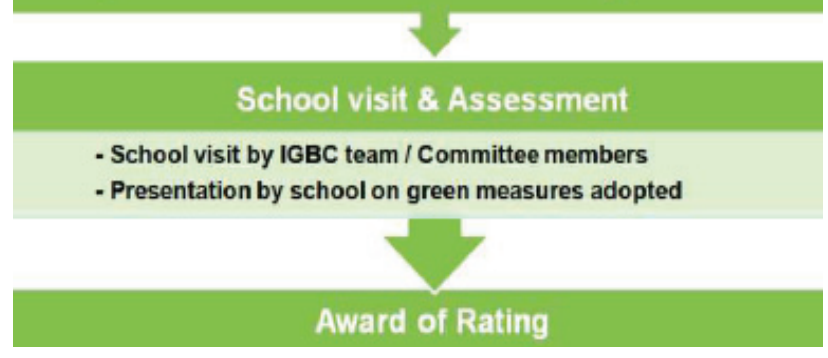

Figure 1. IGBC certification flow chart 
TABLE I.

GREEN FEATURES AND THEIR WeIGHTAGE

\begin{tabular}{|l|l|c|}
\hline S.no. & \multicolumn{1}{|c|}{ Green Feature } & $\begin{array}{c}\text { Weightage } \\
\text { (Points) }\end{array}$ \\
\hline 1 & $\begin{array}{l}\text { Site \& Facility } \\
\text { Management }\end{array}$ & 18 \\
\hline 2 & Water Efficiency & 26 \\
\hline 3 & Energy Efficiency & 30 \\
\hline 4 & Health \& Comfort & 14 \\
\hline 5 & Innovation & 12 \\
\hline \multicolumn{2}{|c|}{ TOTAL } & 100 \\
\hline
\end{tabular}

Apart from the green features mentioned in the table I, there are two mandatory requirements which have to be fulfilled are very basic requirements. These can be satisfied effortlessly. Table II shows the levels of certification based on points earned.

TABLE II.

LEVELS OF CERTIFICATION BASED ON POINTS EARNED

\begin{tabular}{|c|c|c|}
\hline S.No & Points Achieved & Rating \\
\hline 1 & $50-59$ & Best Practices \\
\hline 2 & $60-69$ & $\begin{array}{c}\text { Outstanding } \\
\text { Performance }\end{array}$ \\
\hline 3 & $70-79$ & National Excellence \\
\hline 4 & $80-100$ & Global Leadership \\
\hline
\end{tabular}

\section{Methodology}

In this paper, an attempt is made to assess a conventional building at CVR College of Engineering i.e. P.G. block based on the green features of the building. By this, it can be checked how close a conventional building is to a green building. The evaluation of green features is done based on I.G.B.C. recommendations which are provided in their manual for certification of existing schools. The manual is called IGBC green EB O\&M manual for schools provided in IGBC website.

\section{A. Site and Facility Management (Maximum 18 points)}

i) Eco-friendly Commuting Practices. (Max. 4 points)

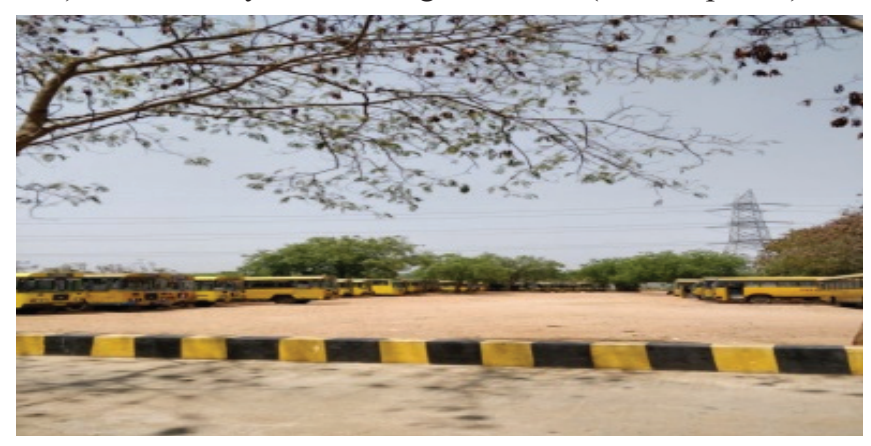

Figure 2. Parking area of the campus

Figure 2 shows the parking facility in the campus for the vehicles of the college.
TABLE III.

POINTS FOR ECO-FRIENDLY COMMUTING PRACTICES

\begin{tabular}{|l|c|l|}
\hline S.No & $\begin{array}{l}\text { Percentage of occupants served with } \\
\text { bus / pool service }\end{array}$ & Points \\
\hline 1 & $25 \%$ & 2 \\
\hline 2 & $50 \%$ & 4 \\
\hline
\end{tabular}

The points scored in this sub-criterion are 4 as per table III. There are 60 dedicated buses for the college.

ii). Eco-friendly landscaping practices. (Max. 2 points)

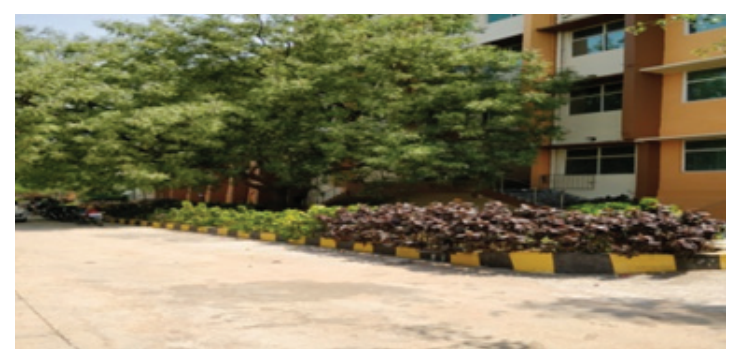

Figure 3. Landscape around the building

TABLE IV.

POINTS FOR ECO-FRIENDLY LANDSCAPING PRACTICES.

\begin{tabular}{|l|c|l|}
\hline S.No & $\begin{array}{l}\text { Percentage of organic fertilizers used } \\
\text { or use of locally adaptive plants }\end{array}$ & Points \\
\hline 1 & $50 \%$ & 1 \\
\hline 2 & $75 \%$ & 2 \\
\hline
\end{tabular}

All the plants in the campus are locally adaptive which require less amount of water for their growth. The points scored in this sub-criterion are 2 as per table IV. The landscape is shown in figure 3.

iii). Heat Island Reduction. (Max. 4 points)

TABLE $V$.

POINTS FOR HEAT ISLAND REDUCTION, NON-ROOF

\begin{tabular}{|l|l|l|}
\hline S.No & $\begin{array}{l}\text { Percentage of shaded non-roof } \\
\text { hardscape areas }\end{array}$ & Points \\
\hline 1 & $50 \%$ & 2 \\
\hline 2 & $75 \%$ & 4 \\
\hline
\end{tabular}

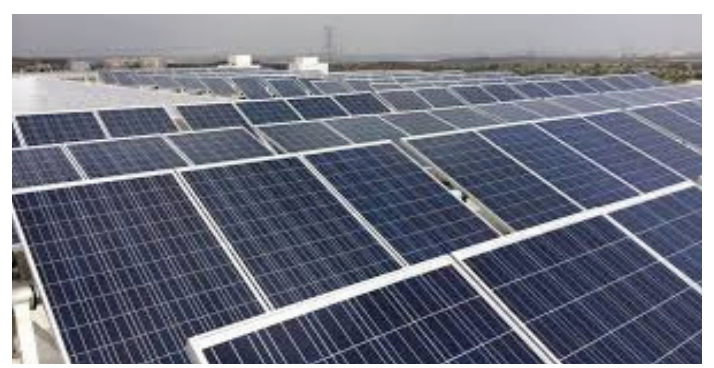

Figure 4. Solar panels on the building

The points scored in this sub-criterion are zero as there are hardscape areas covered with tree canopy/open grid pavers/ solar panels.

iv). Heat Island Reduction, roof. (Max. 4 points) 
TABLE VI.

POINTS FOR HEAT ISLAND REDUCTION, ROOF

\begin{tabular}{|l|l|l|}
\hline S.No & $\begin{array}{l}\text { Percentage of roof area with high } \\
\text { reflective materials. }\end{array}$ & Points \\
\hline 1 & $50 \%$ & 2 \\
\hline 2 & $75 \%$ & 4 \\
\hline
\end{tabular}

The points scored in this sub-criterion are 2 as more than $50 \%$ of the roof is covered with solar panels as shown in figure 4.

v). Outdoor Light Pollution Reduction. (Max. 2 points)

The points scored in this sub-criterion are 2 as the college functions only during day time.

f) Building Operation \& Maintenance. (Max. 2 points)

The points scored in this sub-criterion are zero as scoring credit points in this sub-criterion requires HVAC systems, Lighting systems, etc. which are not provided in the college.

\section{B. Water Efficiency (Maximum 26 points)}

i). Water efficient fixtures. (Max. points 6)

The points scored in this sub-criterion are zero as there are no water efficient fixtures in the building.

ii). Rain Water Harvesting. (Max. points 6)

TABLE VII.

POINTS FOR WATER EFFICIENT FIXTURES

\begin{tabular}{|l|c|l|}
\hline S.No & $\begin{array}{l}\text { Percentage of rain water harvested on } \\
\text { site from roof and non-roof areas }\end{array}$ & Points \\
\hline 1 & $25 \%$ & 2 \\
\hline 2 & $50 \%$ & 4 \\
\hline
\end{tabular}

The points scored in this sub-criterion are zero as there are no rain water harvesting pits.

iii). Waste Water Treatment. (Max. points 4)

The points scored in this sub-criterion are 4 as there is a Sewage Treatment Plant. $100 \%$ of waste water generated in the campus is treated on-site and safely disposed.

iv).Waste Water Reuse. (Max. points 4)

TABLE VIII

POINTS FOR WASTE WATER REUSE

\begin{tabular}{|l|c|l|}
\hline S.No & Percentage of treated water reused & Points \\
\hline 1 & $75 \%$ & 2 \\
\hline 2 & $100 \%$ & 4 \\
\hline
\end{tabular}

The points scored in this sub-criterion are 2 as the treated waste water is used for watering plants. v). Water Metering. (Max. points 4)

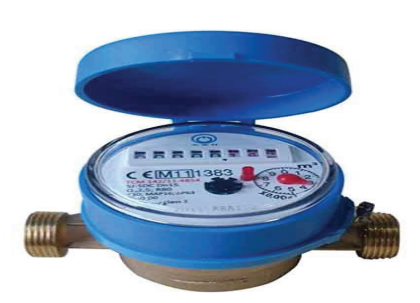

Figure 5. Water meter in the building

The points scored in this sub-criterion are 4. The meters used can be seen in figure 5 .

vi). Turf Area. (Max. points 4)

The points scored in this sub-criterion are zero as the turf area is very high. In order to score points in this subcriterion, there should be less turf area.

\section{Energy Efficiency (Maximum 30 points)}

i). Improved Energy Performance (Max. points 14)

The main intent of this sub-criterion is to reduce the illeffects on environment by enhancing the energy efficiency of the building. The points are given as 2, 4, 6, 8, 10, 12 and 14 based on the Energy Performance Index (EPI) for different climates. The annual energy consumption of the building under study doesn't achieve the limits mentioned in the IGBC manual.

The points scored in this sub-criterion are zero.

ii). On Site Renewable Energy. (Max. points 6)

TABLE IX.

POINTS For ON SITE RENEWABLE ENERGY

\begin{tabular}{|l|c|l|}
\hline S.No & $\begin{array}{l}\text { Renewable energy as a percentage of } \\
\text { total energy consumption }\end{array}$ & Points \\
\hline 1 & $2.5 \%$ & 2 \\
\hline 2 & $5 \%$ & 4 \\
\hline 3 & $7.5 \%$ & 6 \\
\hline
\end{tabular}

The points scored in this sub-criterion are 6 as more than $10 \%$ of renewable energy is generated at site.

iii). Off Site Renewable Energy. (Max. points 6)

TABLE X.

POINTS FOR OFF SITE RENEWABLE ENERGY

\begin{tabular}{|l|l|l|}
\hline S.No & $\begin{array}{l}\text { Percentage of annual energy } \\
\text { consumption }\end{array}$ & Points \\
\hline 1 & $25 \%$ & 2 \\
\hline 2 & $50 \%$ & 4 \\
\hline 3 & $75 \%$ & 6 \\
\hline
\end{tabular}

The points scored in this sub-criterion are zero.

iv). Energy Metering. (Max. points 4)

This should demonstrate that the facility has energy metering and monitoring for the following applications: 
- $\quad$ Renewable energy generation

- $\quad$ Power backup systems

- Interior lighting consumption

The points scored in this sub-criterion are 4 as the building has all the mentioned requirements.

\section{Health and Comfort (Maximum 14 points)} 2)

i). Carbon dioxide Monitoring and Control (Max. points

The main intent of this sub-criterion is to monitor carbon dioxide levels continuously and control it. This should be provided for occupant's health and well-being.

The points scored in this sub-criterion are zero.

ii). Isolation of Pollution Equipment \& Systems (Max. points 2)

The purpose is to reduce the exposure of building residents to dangerous indoor pollutants which badly affect indoor air quality and residents health.

The points scored in this sub-criterion are zero. 2)

iii). Eco-friendly housekeeping chemicals (Max. points

The intent is to encourage housekeeping chemicals which are not hazardous to health of the occupants.

The points scored in this sub-criterion are zero.

iv). Thermal comfort and indoor room temperature (Max. points 2)

The intent is to provide comfortable thermal indoor environment to promote productivity and well-being of occupants.

The points scored in this sub-criterion are 2.

v). Facilities for differently abled people (Max. points 4)

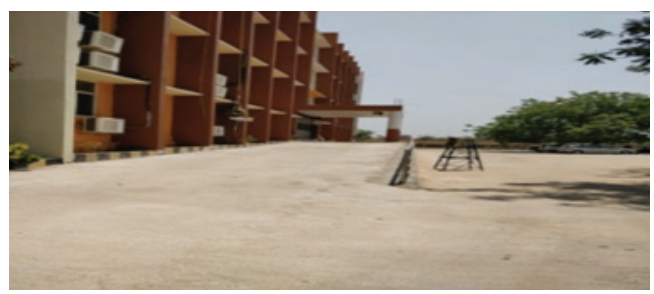

Figure 6. Ramp for differently abled people

Figure 6 shows the ramp provided for differently abled people. The points scored in this sub-criterion are 4 .

vi). Occupant well-being facilities (Max. points 2)

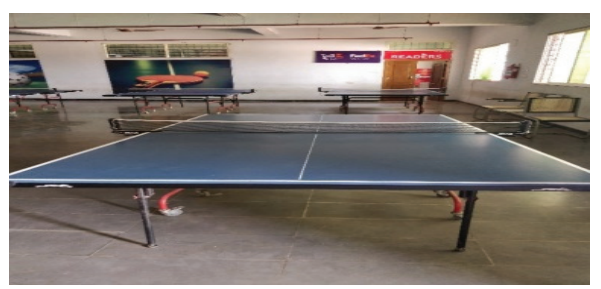

Figure 7. Indoor sports facility for occupants

The intent is to provide amenities to improve physical fitness and emotional well-being of the occupants. Figure 7 shows the indoor games facility in the campus.
The points scored in this sub-criterion are 2.

\section{E. Innovation Category (Maximum 10 points)}

The purpose is to inspire innovation in the performance of existing buildings to reduce the negative impacts on environment. Two points can be achieved if there is at least one IGBC accredited professional in the campus.

The points scored in this sub-criterion are zero.

The sum of all the points scored in all the green features is 48 . Figure 8 shows the points scored under different green features against maximum points.

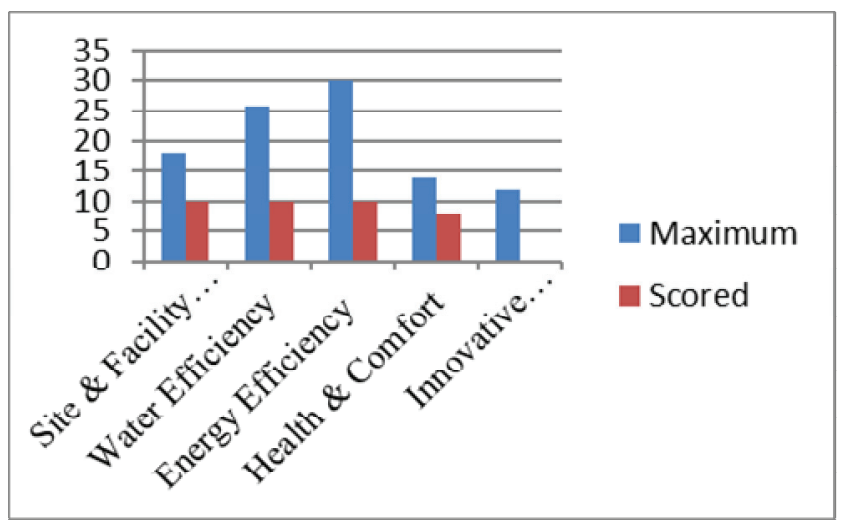

Figure 8. Maximum points VS Scored points

\section{Discussions \& Conclusions}

Sustainable or green buildings provide many tangible and intangible benefits to the occupants. The building rating/assessment systems are also very much useful in planning. The building assessment tools play an important role in planning by helping the planners manage the built environment and also in providing incentives for sustainable or green building.

After analyzing a conventional building based on its green features, a conventional building can easily be transformed into a green building by adapting simple sustainable principles. The first green feature or criteria as per IGBC certification system is site and facility management, which has a maximum score of 18 . The points scored by the building in this criteria are 10 . The subcriterion such as eco-friendly commuting practices, ecofriendly landscaping practices, heat island reduction of roof and outdoor light pollution reduction. But the sub-criterion such as heat island reduction of non-roof and building operation and maintenance could not score points. This aspect of the building can be improved by surface parking, open grid pavers or by planting trees so as to get the shade from the canopies. The building operation and maintenance performance can be improved by providing HVAC systems such as chillers and cooling towers.

The second green feature or criteria is water efficiency. The total points scored in this criterion are 10 out of 26 . This shows that the building the score not even $50 \%$ of the maximum score and there is a lot of scope for improvement. Analyzing the first sub-criterion, ordinary water fixtures can be replaced with water efficient fixtures to save a lot of 
water. By doing so, 6 points can be scored in the first subcriteria. There is also a long term benefit of saving water from being wasted. The second sub-criterion is rain water harvesting. The main intent of this is to capture at least $25 \%$ of runoff volumes from non-roof and roof areas. This can also be done at less cost, thereby improving the score and thereby moving still closer to a green building. The other sub-criterion where no points are scored is the last one i.e. reducing the area of turf in the landscaping to reduce the water consumption. This can be done by placing potted plants in place of turf and increasing landscape areas on basements, roofs, etc.

The third green feature or criteria is Energy efficiency which carries 30 points, i.e. $30 \%$ of the total points. But the points scored are only 10 . In the first sub-criterion, the points scored are zero out of 14 as the annual energy consumption of the building under study doesn't achieve the limits mentioned in the IGBC manual. At least minimum points can be achieved by placing automatic sensors for switching on and off for lights, fans and air conditioners in the building. Studies show a greater improvement in energy efficiency after installing automatic sensors in the building. The other sub-criterion where there is a scope for improvement is the third one i.e. offsite renewable energy. This reduces the use of energy generation through fossil fuels. At least 2 points can be achieved by utilizing $25 \%$ of annual energy from offsite renewable energy sources. The other sub-criterions have scored well.

The fourth green feature is health and comfort. The total points scored are only 4 out of 8 . The first sub-criterion, carbon di-oxide monitoring and control weigh 2 marks. These points can be easily achieved by placing carbon dioxide sensors and maintain $\mathrm{CO}_{2}$ level of less than 530 ppm within the building. The next sub-criterion is isolation of polluting equipment and systems, weighing 2 points. This can be obtained by isolating the areas and room such as janitor rooms, printer/Xerox rooms. These areas should be provided with exhaust systems. The third sub-criterion is eco-friendly housekeeping chemicals. This requirement can be met by using housekeeping chemicals which meet GS-37 or other Indian standards and two points can be achieved.

The last green feature is Innovation. The total weightage is 12. By using some innovative methods which are not mentioned in the manual to reduce the load on the environment, a few points can be achieved. Having an IGBC accredited professional can fetch 2 points. This can be done by encouraging the occupants of the building to take IGBC accreditation test. This test can be cleared after undergoing a two-day training program at IGBC office.
It can be concluded that by following some basic standards, mentioned in this paper, a conventional existing building can be transformed into a green building. It has to be noted that this evaluation of green features is done based on the assumption that the building under study has followed all the mandatory requirements mentioned in the manual.

\section{REFERENCES}

[1] Abanda., F and Byers, L. (2016). "An investigation of the impact of the building orientation on energy consumption in a domestic building using emerging Building Information Modeling (BIM).”Energy 97., 10.1016/j.energy.2015.12.135

[2] Attom., M, Abed., F, Elemam., M, Nazal., M, and ElMessalami, N. (2016). "The effect of treated waste water on compaction and compression of fine soil" World Academy of Science, Engineering and Technology, International Journal of Civil, Environmental, Structural, Construction and Architectural Engineering.

[3] Boonstra., C. and Petterson, T.D. (2003) "Tools for environmental assessment of existing buildings" (online) Sustainable Building and Construction", UNEP Industry and Environment, April 2003

[4] Guggemos., A.A. and Horvath, A. (2006). "Decision support tool for assessing the environmental effects of constructing commercial buildings", Journal of Architectural Engineering, 2006, pp. 187-195.

[5] Gupta, A., and Kumar, A. (2010). "Composite materials: addressing the climate change." Asia Pacific Business review., 10.1177/097324701000600107

[6] Hikmat., H. Ali and Saba, F. Al Nsairat. (2008). "Developing a green building assessment tool for developing countries - case of Jourdan”. Built and Environment 44, pp. 1053-1064

[7] Indian Green Buildings Council (IGBC) - "Green existing buildings operation and maintenance" abridged reference guide, April 2013.

[8] Pamu Yashwanth and Kona Mahesh (2019). "A comparative study on green building rating systems in India in terms of energy and water". CVR Journal of Science and Technology. pp. 21-25

[9] Pamu Yashwanth, VSS Kumar, M.R. Rajagopal and Kona Mahesh (2019). "A comparative study on green building rating systems in India for existing schools, National Conference on Innovations in Civil Engineering through Sustainable Technologies, September 2019.

[10] Sev, A. (2009a). "A comparative analysis of building environmental assessment tools and suggestions for regional adaptations". Civil Engineering and Environmental Systems, Vol. 28, No. 3, September 2011, pp. 231-235

[11] Viera, S.(2011). "Green building standards and certification systems". Washington DC: Steve Winter Associates.

[12] Waidyasekara., K.G.A.S, De silva., M.L, and Rameezdeen, R. (2012) Value of sustainable use of water in construction industry, 2nd International Conference on Sustainable Built Environment, 14-16 December 2012 at Kandy, Sri Lanka. 